a) Independent Scholar, France

\title{
TWO DIPUTES OF METHODS, THREE CONSTRUCTIVISMS, AND THREE LIBERALISMS Part II
}

\section{The Methodenstreit from the point of view of constructivist history of sciences}

According to historians of science the first scientists were Galileo Galilei (1564-1642) and William Gilbert (1544-1603) [1, p. 68]. Both used the actively experimental method, which includes specially organised observation, for example on the basis of a constructed telescope. Galileo was convinced that the universe is a book that is written in the mathematical language, and the symbols of this language are geometrical figures like triangles and circles. Without the help of these symbols "it is impossible to comprehend a single word of it [the book of the universe]; without of which one wanders in vain through a dark labyrinth" [2, p. 75]. He strongly believed in the force of mathematical models which once constructed can be used to understand the reality. This belief had a religious basis: "God has made the world an immutable mathematical system, permitting by the mathematical method an absolute certainty of scientific knowledge" (Ibid., p. 82). Gilbert, who apparently did not share this belief, was the fa-

\footnotetext{
${ }^{1}$ The part I of the article has been published in the previous issue of the journal. (c) Yefimov V. M. Text. 2015.
}

ther of nonmathematical scientific current (Ibid., p. 163). Another scientist who tremendously contributed to the formation of rules of scientific research was Robert Boyle. Following Gilbert's practice he championed the method of reasoned analysis of sensible facts, confirmed by exact experiment: "Experience is but an assistant to reason, since it doth indeed supply information to the understanding but the understanding still remain the judge and has the power or right to examine and make use of the testimonies that are presented to it" (Ibid., p. 170-171). Boyle was one of the organisers of the Royal Society of London for the Improvement of Natural Knowledge known as the Royal Society of London. It is his vision of scientific research which was institutionalised in the framework of associations of its practitioners, one of the first of which was the above mentioned Royal Society of London.

The Royal Society of London was founded in 1660 by members of one or two either secretive or informal societies already in existence. The origins of the Royal Society lie in an «invisible college» of natural philosophers who began meeting in the mid-1640s to discuss the ideas of Francis Bacon. The motto of the Royal Society, «Nullius in Verba» («Nothing in words») or in other words «Demonstration by facts 
and not by words», signifies the Society's commitment to establishing the truth of scientific matters through experiment rather than through citation of authority and logical reasoning. The Society was to meet weekly to witness experiments and discuss what we would now call scientific topics. The history of science since 1660 is closely intertwined with the story of the Royal Society. Approximately at the same time similar societies were created in Italy (Florentine Accademia de Cimento in 1657) and France (Parisian Académie Royale des Sciences in 1666). These societies "represented alternative organisational forms to the universities... The new societies aimed to provide a novel organisational form uniquely suited to the new practice; they made the production of the new knowledge, rather than the just guardianship of and commentary on the old, central to their identity; and they aimed, with varying success, to link the progress of science to civic concerns rather than wholly scholarly or religious ones" [3, p. 133]. The societies "placed high value on the necessity of disciplined collective labour in the making of proper natural knowledge" (Ibid.) and "manifested a pronounced concern for orderliness and the rules of proper behaviour in making and evaluating natural knowledge" (Ibid.). The Royal Society was dominated by scholars-gentlemen. They considered "veracity to be underwritten by virtue. Gentlemen insisted upon the truthfulness of their relations as a mark of their condition and their honour. The acknowledgement of gentlemanly truthfulness was the acknowledgment of gentlemanly identity" [4, p. 410].Objectivity of the truth-seeking by gentlemen in the process of evaluating testimony of experiments and scientific debate concerning them was favoured by gentlemen' material independence: "Free action and integrity were seen as the condition for truth-telling, while constraint and need were recognised as the grounds of mendacity" (Ibid.).

As it is well known, histories are always written by winners. The winner in "the struggle over the soul of economics, institutionalist and neoclassical economists in America between the wars" [5], were the latter and during several decades they produced absolutely distorting discourses concerning the German historical and ethical school and American institutionalism. Among multiple negative labels are non-scientific, atheoretical, inductive, unproductive, useless, normative. Economists produce texts. These texts can be of two types. The first type of texts concerns studies of «what is», that is of existing economic objects and phenomena, and the second represents reasoning about «what ought to be» in economic matters. If our understanding of science corresponds to the tradition created by the Royal Society of London for the Improvement of Natural Knowledge, then we cannot consider the latter type of texts as scientific. Nevertheless, the science practiced and preached by this Royal Society has never been value-free. Without any doubt, they studied "what is" but such its prominent members as Robert Boyle and Isaac Newton were devout Christians and enthusiastic students of the Bible. Both of them wrote not only scientific but also theological texts. Their faith influences their research activity in the sense that it created for it very high motivation: to discover the design of the Creator.

Science can be considered as a social organism. The Royal Society at the beginning of its activity was a very small social organism. Now science is a huge global social organism with its formal and informal rules of recruitment, promotion, publication, etc. These rules are an evolutionary result of ideological, political and financial influences from outside and inside of scientific communities and of beliefs shared by members of these communities. It is quite easy to understand why in the case of economics these rules lead the communities of economists to the theological character of their discipline. It is important to understand why, in spite of all these influences, natural sciences continue to bring to mankind means to dominate the nature and influence in a spectacular way its material environment. Already Charles Peirce saw the research as a collective action of investigators. He had remarked a seemingly magic capacity of scientific communities by observing and by analysing something separately, gradually to converge on the results of the investigation. The cause of this convergence is the same type of "resistance" of objects of study to different investigators. «Nothing in words» as one of the main values and methodological principles of natural scientific communities reinforce the consideration of the character of this "resistance" as the main argument in the discourse inside of scientific communities. As long as communities of economists share neither this value nor this methodological principle, economics will remain primarily secular theologies.

Charles Peirce also gives us the key to understanding the functioning of institution maintaining a theological type of thought: "Let an institution be created which shall have for its object to keep correct doctrines before the attention of the people, to reiterate them perpetually, and to teach them to the young; having at the same time power to prevent contrary doctrines from being taught, advocated, or expressed. Let all possible causes of a change of mind be removed from 
men's apprehensions. Let them be kept ignorant, lest they should learn of some reason to think otherwise than they do. Let their passions be enlisted, so that they may regard private and unusual opinions with hatred and horror. Then, let all men who reject the established belief be terrified into silence" [6, p. 117]. It is exactly what Alfred Marshall has initiated as the institution of economics in England at the end of the 19th century and what later expanded throughout the world.

William Cunningham, an English advocate of German-type economics, provides the following testimony of the situation in the community of economists in England of that time: "Anyone who has refused to follow the economic fashion of recent years in England must have been greatly hampered in his efforts to pursue his own studies or guide those of others; boards of studies would exercise a galling control, and editors and publishers would view his writing with suspicion ... There was no need for the English adherents of the realistic school of economists to complain when obstacles were placed in the way of their work, and avenues of publication were closed against them" [7, p. 327]. In this paper, published in the USA, he discussed the attitude of Professor Marshall and his disciples towards the German-type economics: "In Germany ... a veritable revolution has taken place in economic studies during the last fifty years ... a revolution in the whole conception and character of economic studies: it has come to be concerned with the observation and study of the actual economic conditions of society in the past and the present; not merely with the formulating of hypothetical principles, which the sciolist was only too apt to convert into ready made receipts for removing any of the ills of social life. It is not a little remarkable that while this revolution has taken place in Germany and to some extent in America, England should have been almost untouched by it” (Ibid., pp. 317-318). He also criticised the Mill's methodology on which Marshallian economics was based: "The Germans began to devote themselves to the past, and thus opened up a field for discriminating observation and accumulation of facts. Mill took no pains about the past and comparatively little with the details of contemporary experience. His eyes were fixed on the time to come ... So far as its matter is concerned, the work did not stimulate to observation and research. Nor did the character of the science as treated by Mill undergo any decided change: he regards it as a hypothetical science" (Ibid., p. 319). Now communities of academic economists continue to follow the Millian methodology.

At present most of the economists consider economics as theory or theories. To do econom- ics mean for them to develop or to apply theories. According to Knorr Cetina "much of laboratory science in molecular genetics neither directly draws upon nor it seems terribly involved with establishing, theoretical representations. In molecular genetics, theoretical statements may indeed be post hoc 'representations' of materials" [8, p. 120]. Apparently neither Latour nor KnorCetina would agree with Milton Friedman's famous statement: "A theory is the way we perceive 'facts', and we cannot perceive 'facts' without a theory" [9, p. 34]. Some sincere mainstream economists do not agree with Friedman either: "By regularities I mean phenomena that repeatedly appear in similar environments at different points in time and different locations. I have the impression that as economic theorists, we hope that regularities will miraculously emerge from the formulas we write leisurely at our desks. Applied economists often feel the need for a model before they mine data for a pattern or regularity. Do we really need economic theory to find these regularities? Would it not be better to go in the opposite direction by observing the real world, whether through empirical or experimental data, to find unexpected regularities? Personally I doubt that we need pre conceived theories to find regularities." [10, p. 873]. Finally what we learn from Knorr Cetina' investigation, it is the challenge to the accepted view of a unified science even in the framework of natural sciences. Research procedures can sharply differ in different disciplines, but if they represent interacting with the "resisting" entities under study, they certainly can be classified as scientific research.

Born as a political/moral philosophy, British political economy has been presented by J.S. Mill as a science on the basis of its wrong discourse about science [11] later developed in his "System of Logic" [12]. The marginalist revolution of Walras, Jevons and Menger followed Mill by accepting a priori method as their method. With the start in Great Britain at the end of the 19th century of the profession of economics as a profession of university teacher of this discipline, Marshall guided the process of institutionalisation of economics on the basis of marginalism and Mill's methodology. He initialised in 1890 the creation of the British Economic Association (The Royal Economic Society), in order to strengthen the British institution of the economics of which he was the designer. Formally it could look like the Royal Society initiated by Boyle but in reality it resembled much more a guild, i. e. an association of craftsman in a particular trade. Institutionalisation of economics in Germany, also on the basis of the profession of university teachers of economics, 
took a totally different path nevertheless. German VereinfürSozialpolitik can be rightly considered as a functional analogue for the economics of the Royal Society of London for the Improvement of Natural Knowledge.

Founders of the Royal Society were convinced that the universe works in accordance with the laws of nature which God established for its order and control. One of the most influential of them, Robert Boyle, in his book [13] explained that the study and dominion of nature is a duty given to man by God. The first scientists were very much motivated in their research activity because they thought that they were discovering the design of the Creator and in this way they approach the humanity to God. The community of researchers of the Royal Society did not earn their living by their investigating activity. All of them had independent sources of existence that had no connection with their research work. Thus, the Royal Society cannot be considered as a guild. A century later, Johann Fichte, the second after Humboldt founder of the institution of research university, saw the motivation of researcher in a different way: "The true vocation of the scholar is the most widely extended survey of the actual advancement of the human race in general, and the steadfast promotion of that advancement.” [14, p. 54]. Institutionalisation of German economics happened in Humboldtian university and its architect, Gustav Schmoller, followed the ideas of Fichte. In this way, Schmollerian Verein similar to the Royal Society had not been conceived as a guild. The foundation of the Verein took place quite quickly after the German unification. Schmoller has taken for the community of German economists a more modest position than Fichte for scholars in general: most widely extended survey of the actual advancement of the young German nation, and the steadfast promotion of that advancement. United Germany needed national unity and the political crisis of early capitalism created danger for this unity. This danger came from the existence of the so-called "social question".

Germany was behind Britain and France in industrialisation and urbanisation. Schmoller and his colleagues were very much impressed by the studies of Fridrich Engels over the British conditions [15] and of Lorenz von Stein over the French conditions. They considered these studies as indicators of what could happen in Germany in the future: "Engels's vivid descriptions of the commercial vibrancy and man-made hell produced as a consequence of industrial development, chaotic urbanisation, the litany of abuses and deprivations inflicted on the working class and their re- sultant moral and ethical degeneration, but also of the failure of charity, the ruthlessness of factory owners, and complacency of the British government in dealing with these problems caused a sensation in Germany" [16, p. 108-110]. Lorenz von Stein came to the conclusion that "French society was driven by class-centred political conflict produced by increasing social inequality - a product of free market competition. Socialism and communism were thus simply an expression of justified proletarian aspirations to attain social equality"(Ibid., p.109). In his speech at the inaugural meeting of the VereinfürSozialpolitikSchmoller "warned of the threat of social revolution engendered by the division between employer and worker, propertied and propertyless classes, and suggested that popular economic beliefs concerning commercial freedom and economic individualism could well create even greater disorder, rather than the rosy future they imagined" [17]. According to him "only the German state was in a position to reduce social tension and foster national unity, for it stood above selfish class interests, 'legislating, guiding administration with a just hand, protecting the weak, raising the lower classes" (Ibid.). Representatives of propertied classes denied the existence of the social question, but with national unification and formation of a national government new light had been shed on economic conditions: factory laws, factory inspection, corporative organizations, and courts of arbitration were all dismissed [16, p. 178]. In order to collect and analyse data "the new organisation [VereinfürSozialpolitik] was conceived as a body to exclusively research the social question to provide scientifically derived, general, and above all, practical information on reform to appeal to the parties of the political middle, the public, legislators, and government officials, it was hoped, would then use this 'scientific' information as a basis for policy decisions, and thereby not blinded by the fog of "partisan economics'" (Ibid., p. 179).

Founders of the Verein shared their general frustration with the mode of reasoning of classical economics "that seemed wholly at odds with positivist and materialist scientific climate of the time, when the natural sciences were celebrating success upon success by working empirically" (Ibid., p. 123). Unlike most of the university professors of economics, founders of Verein, Gustav Schmoller and Georg Knapp, received a good training in natural sciences: Schmoller had studied at the University in Tübingen chemistry, physics, mechanical engineering and technology; Knapp studied physics and chemistry in Liebig's laboratory (Ibid., p. 133). The translation of Mill's 
System of Logic into German has been published in 1865 , and like many others, Schmoller noticed the inconsistency of Mill's treatment of social sciences by excluding application to them of experimental approach. According to Schmoller and his colleagues, major sources of social regularity were common morals, ethics, and institutions. Thus, to understand socio-economic phenomena it is necessary "to study all those institutions that had emerged over time to constrain and mould individual behaviour into purposive action and social interaction" (Ibid., p. 160). Their "search for moral commonality to construct new laws and institutions naturally led to historical investigations of those things that formed a common moral sphere and ethically constrained and moulded economic action: customs, norms, conventions, rules, regulations, laws, organisations, corporate bodies and other institutions, and not least, the state" (Ibid., p. 160-161). For Schmoller and his colleagues, social reform was a process of piecemeal institutional adaptation (Ibid., p. 161). On the basis of his historical investigations Schmoller has come to the conclusion that "the state and its bureaucracy could defend the general interest and be forces for social improvement; institutions in the economy provided greater certainty and order to market relations and injected into these a set of moral-ethical norms" (Ibid., p. 168). In this way, institutions were "the means to create for a modern industrial economy a new moral-ethical order" (Ibid).

Thanks to the Verein in the community of German economists, the good professional practice became identified with empirical research. It guided and organised economic research by its agenda-setting standing committees of annual conferences. These conferences were not just meetings of members of the profession sharing with each other results of their research. These conferences were places of debate of commissioned studies. "In advance of conferences, Verein's standing committee held meetings to nominate and vote on the subjects to be discussed at the conferences. Sets of questions were then raised and parameters set for research and fieldwork (or in the case of surveys, detailed questionnaires were drafted and sent out) by a commissioned expert, and increasingly, groups of experts. The results of these investigations and surveys would then be compiled into summary studies that were circulated before conferences ... Following the conferences, commissioned studies were published in the Verein's monograph series, the Schriften des VereinfürSozialpolitik ... To get an idea of the scale of the Verein's research, by 1914 it had published some 140 volumes of its
Schriften of an average length of about 350 pages.”(Ibid., p. 69-70). In many cases Verein received financial support from government departments for the collection of data [17, p. 12]. Results of investigations of German economists affiliated to Verein were published in several academic journals like Schmoller'sJahrbuchfürGesetzgebung, Verwaltung und VolkswirtschaftimDeutschen Reich (Annal for Legislation, Administration, and Political Economy in the German Empire) and JahrbücherfürNationalökonomieundStatistik (Annals for Political Economy and Statistics), chief editors of which were Bruno Hildebrand and Johannes Conrad.

Recent historical findings concerning activities of Schmoller and his colleagues in the Vereinfür Socialpolitik $[16 ; 18 ; 19 ; 20 ; 21 ; 22]$ have showed its non-partisan scientific character. The result of these activities had national and even international value. Thanks to their efforts Germany was one of the first countries to define a «social question» and develop a modern welfare state. Schmoller and his colleagues were successful in convincing the German government in the necessity of the reforms for solving the social question. A decade later of the Verein's foundation, the head of German government, Otto von Bismarck, had the following discourse: ".... the actual complaint of the worker is the insecurity of his existence; he is unsure if he will always have work, he is unsure if he will always be healthy and he can predict that he will reach old age and be unable to work. If he falls into poverty and be that only through prolonged illness, he will find himself totally helpless being on his own, and society currently does not accept any responsibility towards him beyond the usual provisions for the poor, even if he has been working all the time ever so diligently and faithfully. The ordinary provision for the poor, however, leaves a lot to be desired ....". The governmental reform programme included Health Insurance, Accident Insurance (Workman's Compensation), Disability Insurance, and an Oldage Retirement Pension, none of which were then currently in existence to any great degree. Bismarck opened debate on the subject on 17 November 1881 in the Imperial Message to the Reichstag, using the term practical Christianity to describe his programme. Based on Bismarck's message, the Reichstag filed three bills designed to deal with the concept of Accident Insurance, and one for Health Insurance. The subjects of Retirement Pension and Disability Insurance were placed aside for the time being. The law concerning them was adopted several years later.

Why constructivist institutionalism at the turn of the 19th and 20th centuries in Germany and the 
United States had been abandoned by communities of academic economists? An understanding of this phenomenon is the central task of this paper. The political economy of Adam Smith was a politi$\mathrm{cal} /$ social/moral philosophy and not a science as it was practiced by first scientists Galileo and Gilbert and has been institutionalised in the framework of the Royal Society of London. Based on traditions of scientific research in natural experimental sciences and on the values of scholars formulated by Humboldt and Fichte, German professors of economics have developed an institution of economics with its central element VereinfürSocialpolitik. This institution was oriented not for the self-protection of the community of economists but for the fulfilment of the mission: help to the state to solve the social question and to protect the new German nation from a national catastrophe. Two decades later the institutionalisation of economics in England took place. The process happened in an absolutely different institutional environment, not in a Humboldt's research university, but in an almost medieval type of universities where the curriculum was dominated by mathematics, classics and theology. The architect of the British institution of economics, Alfred Marshall followed in its design the established university spirit. In addition, the creation of the institution of economics like a secular theology was influenced by his lost of the Christian faith and his adoption of utilitarian ideology (Bentham). In this change of belief, he followed the dominant cultural tendencies of his social environment. It has predetermined his professional choice not to be involved in hard and time-consuming empirical research of socio-economic realities but to start developing abstract a priori constructions. This choice has been supported by the distorted interpretation by John Stuart Mill of the process of knowledge acquisition. This interpretation gave to a priori constructions of political economists an aureole of science.

Both Schmoller's and Marshall's economics were responses to the existence of the social question; in England it was even sharper than in Germany, but the responses of different types. The former was oriented to helping the state to solve this problem by improving conditions of the working class by introducing new social legislation, and in this way, to prevent social unrest. The latter was oriented to create scientifically looking ideological construction legitimating the existing social order and conditions, and in this way to achieve the same goal, to prevent social unrest. Once established the institution of Marshallian economics attract much easier the affiliation of those who consider the discipline of economics more like a craft than as a vocation. The work of Schmollerian economists as researchers and teachers is much more difficult than that of Marshallian economists. Frequent surveys/fieldwork and constant adaptation of courses to changing realities are much more time and labour consuming than the desk work of "a priori theorists". Very quickly, the community of economists-craftsmen can become an inaccessible fortress for those who would like to practice economics as a vocation with primarily socially-oriented altruistic aspirations. The problem with Schmollerian economics in comparison with Marshallian economics is not only social but also economic and political. Surveys and fieldwork request strong financial and political support on behalf of the governments (local and/or central). The political support of Schmollerian types of scholars is necessary because their research activity can discover undesirable for owners/managers details of the functioning of their private enterprises. The resistance to Schmollerian economists can take place in the domain of surveys and field studies' organisation and financing or in the domain of the recruitment and promotion of teachers/researchers controlled by university boards with businessmen as its members. All these factors probably played their role in the post-Schmoller's economics in Germany.

The interwar economic and political crisis could not be of any influence on the German community of economists. The Vereinfür Sozialpolitik was dissolved in 1936 with the arrival to power of Nazis. After World War II, the military presence of the USSR in Eastern Germany and of the USA in Western Germany have predetermined the reign of the Marxist-Leninist political economy in one part of Germany and of neoclassical economics in the other part. At least since the fall of the Berlin wall "neoclassical economics was and still is dominant in Germany ... Until recently it was said that 'Schmoller is forever condemned and castigated' [21, p. 72]. Nevertheless "it is surprising how many younger (German) scholars are interested in a reconstruction of institutionalism and historicism and how few survive the crowding out of the profession after their dissertation" (Ibid., p. 97).

Dispute of methods, or Methodenstreit, between Gustave Schmoller and Carl Menger, can be considered as a repetition of a similar dispute taking place more than two hundred years earlier between Robert Boyle and Thomas Hobbes. Schmoller-Menger dispute started soon after the beginning of the institutionalisation of experimentally oriented economics which happened with the creation in 1873 of the VereinfürSozialpolitik. Boyle-Hobbes dispute started in 1660, when the 
Royal Society of London had been founded, the cradle of the institution of science. The activities of both societies were similar in several respects: they represented efforts to collect data in the framework of experimental situations, working out of detailed reports and collective evaluation of obtained results. The reports of the Royal Society served to enlarge the number of witnesses of experiments and in this way "to make virtual witnessing a practical option for the validation of experimental performances" [22a, p. 69]. Boyle insisted on his "lack of preconceived expectations, and, especially, of theoretical investments in the outcome of experiments (Ibid., p. 68). Now, it is almost forgotten that Hobbes was not only a political philosopher but also a physicist (natural philosopher). He criticised the experimental way of producing physical knowledge, and he insisted on rationalist methods, as Menger also did, of obtaining knowledge. Both of them proceeded from definitions through a deduction to consequences. For Hobbes, as for Menger, the model of "science" was geometry, which "yielded irrefutable and incontestable knowledge"(Ibid., p. 100). On the contrary, the "the Royal Society advertises itself as a 'union of eyes and hands"” (Ibid., p. 78). Hobbes thought that "the factual knowledge, it was true, had a valuable role to play in constituting our overall knowledge, but it was not of the sort to secure certainty and universal assent" (Ibid., p. 102).

Boyle did win the dispute, Schmoller did loose. In my opinion, it happened for the following main reasons. The motto Nullius in Verba (demonstration by facts and not by words) has become the rule on the basis of the institution of natural sciences, the most important feature of the scientific culture. From the very beginning activity of researchers according to this rule did not contradict interests of powerful groups of the society, and later such groups were even very much interested in the existence of this rule because of profitable practical results. It did not occur in economics just because of the strong resistance of such groups to experimental social research. They saw much more danger than benefit for them in this type of research. On the contrary, they were interested in abstract theoretical constructions justifying laissez-faire. This kind of constructions corresponded to deeply enrooted scholastic traditions of European universities to teach theology and linked with it philosophy. In the framework of these traditions, the mathematics was considered as a summit of scientific approach. Powerful groups of society supported these traditions in the economics profession and made all possible to suppress newly born experimental current of economics. Can you im- agine, in what world, from the point of view of technology, we would live now if Hobbes' concept of science had overcome? The humanity remained at the technological level of the 17th century. Now imagine the world's history of the 20th century if the Schmoller's concept of economics would have overcome. I think that, in this case, many human catastrophes could have been avoided.

\section{Three constructivisms and three types of economics}

In this section, I will refer to ideas exposed in the first section of the paper as epistemological constructivism. In the previous section 3 of this paper, I have shown that the economic school of Gustav Schmoller followed epistemological constructivism, and in this way followed natural sciences' research traditions. Schmoller has succeeded to find an adequate for social sciences form to follow these traditions by determining rules of behaviour as the source of social regularities and Wilhelm Dilthey's hermeneutics as the way of investigation of these regularities. In fact, he anticipated many ideas of the social constructivism. The social constructivism [23] provided a building material with the help of which it became possible to create a new vision of scientific research and at the same time it can be considered as a frame social theory.To my mind, the attractiveness of the German historical and ethical school comes from the fact that it produced such a rich set of ideas concerning the social world that they continue to reappear later. One of its central ideas has been entered in the social constructivism: "Institutions always have a history, of which they are the products. It is impossible to understand an institution adequately without an understanding of the historical process in which it was produced" (Ibid., p. 72). A follower of Schmoller, John Commons explicitly admitted that his institutional economics was based on the philosophy of pragmatism of Charles Peirce and John Dewey. The philosophy of Peirce is closely linked with the notions of belief and habit. The belief "involves the establishment in our nature of a rule of action, or, say for short a habit ... The whole function of thought is to produce habits of action ... To develop its meaning, we have, therefore, simply to determine what habits it involves" [6, p. 129, 131]. For Peirce "belief is not a momentary mode of consciousness; it is a habit of mind essentially enduring for some time ... Instead of saying that you want to know the 'Truth', you were simply to say that you want to attain a state of belief unassailable by doubt" $[24$, p. 336]. Based on the Peirce's pragmatism, we can say that social reality is a reality of beliefs and 
habits. It means that this reality is socially constructed $^{1}$ by the processes of institutionalisation ${ }^{2}$, legitimation ${ }^{3}$ and socialisation ${ }^{4}$ [23].

Being constructed by humans the social reality is nevertheless perceived by them as an objective world, they objectivise and reify it: "Reification is the apprehension of human phenomena as if they were things, that is, in non-human or possibly suprahuman terms. Another way of saying this is that reification is the apprehension of the products of human activity as if they were something other than human products - such as facts of nature, results of cosmic laws, or manifestations of divine will.Reification implies that man is capable of forgetting his own authorship of the human world" (Ibid., p. 106). The present day mainstream and heterodox economists are caught in the trap of this reification. So critical realist economists call on to provide explanations in terms of hidden social structures. On the contrary, the constructivist Rom Harréwants "to pay to the means by which socially competent people are produced in the manner of Vygotsky's psychological symbiosis, a mode of production that involves inter personal interaction without the reification of social structures" [26, p. 139]. One type of such structures is referred to as institutions at the basis of which are rules and conventions. Harré claims that "people become members of a society ... by their Vygotskian origins as they acquire competence in practices recognised as correct in their local culture, which is acquire grammar $^{5}$, pick up schemata, scripts and so on, and are trained in good habits. Using these skills they do not produce structures, but a rich, interconnected mesh of meaningful exchanges. To collect up a set of rules and conventions as an institution is a harmless and useful classificatory device, so long as we do not slip into ascribing causal powers to it" (Ibid., p. 138). The study of institutions must be base on discursive approach because "conver-

\footnotetext{
${ }^{1}$ Late Douglass North accepted it: "All the building blocks of the world we live in are a product of our human mind. They do not exist outside us." [25, p. 3].

2 "Institutionalization occurs whenever there is a reciprocal typification of habitualized actions by types of actors. Put differently, any such typification is an institution." [23, p. 72].

3 "The institutional world requires legitimation that is ways by which it can be 'explained and justified." [23, p. 79].

${ }^{4}$ Socialisation may be defined as the comprehensive and consistent induction of an individual into the objective world of a society or a sector of it. It happens when the individual achieves a capacity of the immediate apprehension or interpretation of an objective event as expressing meaning [23, p. 150].

5 "'Grammar' refers not only to the ledger of our linguistic practices but also to the ledger of meaningful actions of every kind" [27, p. 150].
}

sations are normatively constrained, so the scientific presentation of our knowledge of the generators of the social world is in sets of rules, that grammars, in Wittgenstein's sense. Grammars represent the tacit schemats, "scripts", narratives and so on that guide the agent in acting with others to continuously create a credible social world, and to repair it when the flow of actions begins to disintegrate into mutually unintelligible fragments. The root process of social life is people as active agents making use of their shared knowledge of grammars to carry out collective projects with others" (Ibid., p. 140).

The characteristic of the dispute between Schmoller and Menger, as a dispute concerning methods applied by economists, is not exact. It was primarily the dispute about the nature of social reality and social regularities, and the character of science that would be able to bring knowledge about these regularities. For Schmoller, social regularities inside a community come from the fact that members of this community follow certain complexes of rules of morals and law which form institutions. These complexes of morals and law are fixed orally in conversations and in written in texts. That is why the science that would be able to bring knowledge about social regularities should investigate conversations and texts where corresponding complexes of rules of morals and law are depicted. The institutionalist tradition coming from Schmolleris closely linked with discursive approach, which is based on a model of man where "the person is considered not only as agent but also as watcher, commentator and critic" $[28$, p. 91]. It means that the rule as an element of an institution "'exists' in and through the practice of citing it and invoking it in the course of training, in the course of enjoining others to follow it, and in the course of telling them they have not followed it, or not followed it correctly. All of these things are said to others and oneself and are heard being said by others" $[29$, p. 33]. That is why "the phenomenon of following a rule is not distinct from descriptions given of it" (Ibid., pp. 33-34).

The legacy of Schmoller is not limited only by his thoughts concerning ontology (what to study) and epistemology (how to study) of economics as a science. He contributed enormously to economics as a social philosophy. Beginning from Quesnay up to now, one of the central philosophical questions of economics is whether human beings can and should construct economic reality or not. The answer of Quesnay to this question was no. The answer to this question by Schmoller was much more nuanced. I take liberty to quote a long passage from one of his works, the first part of which gives the 
answer "yes", while the second part answers rather negatively: "The older economic school of Adam Smith had found its ideal of justice exclusively in the freedom of contracts. Presuming that all men are by nature equal, it demanded only freedom for these equal men, in the hope that this would result in agreements about equal values with equal profits for both parties. It knew neither the social classes nor the social institutions in their significance for economic life; for it the social mechanism was composed exclusively of the activity of individuals and their single agreements. And therefore it could not demand any other kind of justice. This was not wrong, but it was only a part of the «just» which it demanded. We demand to-day above all, besides a just system of exchange, just economic institutions, i.e., we demand that the complexes of rules of morals and law which govern groups of men who live and work together should harmonize with their results with those ideal conceptions of justice which on the basis of our moral and religious conceptions are prevalent to-day, or which are gaining recognition. We do not acknowledge any one of these institutions to be above history, as having always existed or as necessity everlasting. We test the result of every one of them and ask of each: How did it originate, what conceptions of justice have generated it, what necessity exists for it to-day? [30, p. 34-35].

We may characterise the second half of the passage with the negative answer to the above mentioned question as indication on path dependency in social change: "To be sure we also know how to appreciate the value of the institutions transmitted to us, we know that the sacred traditions of the past fill our mind with awe, that even the form of traditional law has a restraining effect on rough characters,that a lasting condition of social peace is based on the greatest possible restriction of formal breach of law. We admit that institutions must never disappear in form and substance, that nations can never create anything wholly new, but must always build on what exists. In this lasting continuity of the whole we have a guarantee that the struggle for that which is good and just will not expire fruitlessly; though this would always happen, if each generation had to begin this struggle anew, and was not furnished with the inheritance of tried wisdom and justice, contained in traditional institutions. We admit that every momentary condition of peace in society, as it is preserved by an existing law of property, inheritance and some other institutions, is more valuable than a dangerously unsettling war for a more just law of property and inheritance, when the traditional law still corresponds to the equilibrium of the forces existing in society and to the prevalent ideal conceptious. In this case, every struggle for more just laws is for the time being hopeless and vain. It can only harm and destroy. Even the most violent revolution cannot replace the mental transformation of men which is the precondition of a more just law. The essential point is always that the force's themselves and the conceptions of justice have changed. Then only can a struggle succeed" (Ibid., pp. 35-36).

Today we can only admire the deep wisdom of Schmoller's thoughts by observing catastrophic consequences of socio-economic-political changes imposed by the West in many parts of the world. Gustav Schmoller consider himself as a follower of James Steuart who wrote: "The great art therefore of political economy is, first to adapt the different operations of it to the spirit, manners, habits, and customs of the people, and afterwards to model these circumstances so, as to be able to introduce a set of new and more useful institutions ... If one considers the variety which is found in different countries, in the distribution of property, subordination of classes, genius of people, proceeding from the variety of forms of government, laws, and manners, one may conclude, that the political economy in each must necessarily be different, and that principles, however universally true, may become quite ineffectual in practice, without a sufficient preparation of the spirit of a people" [31, pp. 2, 3]. Ideas of Schmoller and Sreuart on social change are very close to social constructivism. According to it, rules form institutions if they become reciprocal typification of habitualized actions by types of actors. It happens only if these rules are explained and justified (legitimised) and the actors pass through long practical social training by their immediate social environment (socialisation). Certainly powerful members of society can influence the change of the rules more successfully than non-powerful ones but even they would be forced to wait the habitalization of these rules before they would become effective. No enforcement mechanisms are capable to make the immediate social acceptance of totally different rules to existing ones.

Friedrich Hayek introduced the term 'constructivism' to signify something contrary to his notion of spontaneous order. In its simplest manner, he expressed its meaning by the following formula: "Since man has himself created the institutions of society and civilisation, he must also be able to alter them at will so as to satisfy his desires or wishes" [32, p. 3]. This notion of constructivism, I will call here Hayekian constructivism. Certainly this notion was oriented against ideas of Marx and 
Keynes, and with many of his arguments we could hardly disagree. Nevertheless in his work, which is entitled The Errors of Constructivism, he commits himself at least four mistakes. First, he considers the process of change of the rules of behaviour as exclusively the process of imitations of more successful, efficient rules. The second, we can guess that the only rules he had in mind are the rules enrooted in Western civilisation. The third, in his notion of constructivism, the actor was individual, and a possibility of collective will was not taken into consideration. At last, the fourth, he was not aware of the fact that rules are always expressed and transmitted with the help of language. All four Hayek's mistakes continue to be reproduced by mainstream economists [33]. The present day mainstream economics does not use in its discourses anyone of three above mentioned notions of constructivism. The contemporary heterodox economics does not use these notions either, but is accused by the mainstream to be in the trap of Hayekian constructivism. The social constructivism, as social and political philosophy, once accepted by economists, may have far-reaching consequences. They would be able to convince people that "genuine projects of human emancipation become possible" because "human beings can come to realise that they are people and so active agents trying to realise their projects with others. As such they can come to realise that the constraints that society seems to place upon their pursuit of worth are grammatical, in the sense that Ludwig Wittgenstein gave to that term. The story-lines and conventions in accordance with which people live could be different and new grammars can be created and adopted" [26, p. 142].

The present day economists, divided in mainstream and heterodox, ignore totally epistemological and social constructivisms, and this is one of the main factors of its cognitive sterility and social harmfulness.

Smithian economics is a rewriting of Mandeville's fable on the basis of Quesnay's creed. Its institutional success in universities was due to the fact that this rewriting was done according to standards of moral and political philosophy taught in universities which served to justification and legitimisation of existing social order. Fable's character is conserved in the most sophisticated versions of the present day mainstream [34]. Marxian economics was a philosophical and ideological response to Smithian economics. Both of them correspond to the understanding of science by Hobbes, not by Boyle. German academic economists of the second half of the 19th century followed natural sciences research tradi-
Table 2

Presence of three kinds of constructivisms in three types of economics

\begin{tabular}{|c|c|c|c|c|}
\hline & Founders & 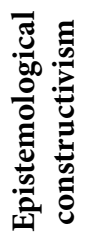 & : & 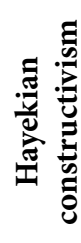 \\
\hline $\begin{array}{l}\text { Mainstream } \\
\text { economics }\end{array}$ & $\begin{array}{l}\text { Quesnay } \\
\text { Smith } \\
\text { Walras }\end{array}$ & - & - & - \\
\hline $\begin{array}{l}\text { Heterodox } \\
\text { economics }\end{array}$ & $\begin{array}{l}\text { Marx } \\
\text { Veblen } \\
\text { Keynes }\end{array}$ & - & - & + \\
\hline $\begin{array}{l}\text { Constructivist } \\
\text { institutionalist } \\
\text { economics }\end{array}$ & $\begin{array}{l}\text { Steuart } \\
\text { Schmoller } \\
\text { Commons }\end{array}$ & + & + & - \\
\hline
\end{tabular}

tion with their experimental method. They were affiliated neither with Smithian nor Marxian economics. Speaking the 15 th of October 1897 at the University of Berlin Gustav Schmollerindicated that two major theories or schools that have dominated economic thinking and action from 1770 are the individualistic and socialist-oriented economics. He underlined that they were both children of the same mother, the old theory of natural laws preached by physiocrats. The individualistic theory by Adam Smith, followed by J.S. Mill and a little more modern socialist theory of the class struggle by Karl Marx, are the product of this theory of natural laws. Both schools believe they can derive from the abstract human nature a complete lens system of the present economy. Both exaggerate, as the entire eighteenth century and the first half of the nineteenth century philosophy, our current ability to know; both want to get a jump, without studying the details, without an exact psychological basis, without extensive prior studies of law and economic history, to economic ultimate truth, and in this way to dominate the world, men and states. But both are just ideologies representing certain ideals for the economy, social life, and all economic and legal institutions. By their method and content, they do not rise to the level of real science[35, p. 191-192].

The scope and method of Schmollerian economics were different from the economics of Smith and Marx. In the scope of their analysis there were not only quantitative variables such as production, consumption, labour, values, prices and capital, but,above all, qualitative entities: institutions; i.e. rules and beliefs. Gustav Schmoller, at that time, wrote: 'The present-day economics (Volkswirtschaftslehre) has come to a histori- 
cal and ethical conception of the state and society, quite different from that which had been formulated by the rationalism and the materialism. It is no longer a mere theory of market and exchange, a kind of political economy of business, which threatened to become a class weapon of the wealthy. It became once again a great political and moral science, which studies production of goods but also their distribution, the phenomena of exchange, but also economic institutions. It puts the man again in the centre of science, rather than goods and capital'(Ibid., pp. 202-203).

\section{Economics and three contemporary versions of liberalism}

In the second section of this paper, I indicated that the historian of economic thought, E. Roy Weintraub, who announced that he develops a constructivist history of economics, does not understand epistemological constructivism correctly. I suppose that it happens not by chance. One of the most important fallibility of modern economics is its self-referential character. Economists usually do not care whether what they are doing is socially useful or not. If a historian of economic thought justify explicitly or implicitly in his writings a socially harmful economic theory, then his work is also harmful. Certainty Weintraub thinks differently: "I do not believe that it is my task as a historian to argue with economists about the right way to do economics, or about whether mainstream economics is on the wrong track or the right track. As a historian, my task is to construct histories of economics, not to reconstruct the discipline of economics. Historical reconstructions writing histories of economics that respect the contingencies of time and place and individual and contexts is both a difficult and an important task for historians of economics" [36, p. 280]. The prominent historian of economic thought, Robert Heilbroner, would not agree with this statement, especially if the 'context' considered by Weintraub is very restricted and does not include decisive political and economic influences from outside of the economics profession. Anglo-Saxon institution of economics created in the framework of universities, very much touched by their medieval history and subordinated to the new capitalist establishment, laid this discipline to the incarnation of the ideology favouring interests of this establishment. Contemporary mainstream economics continues to fulfil the same function: "The social understanding we gain from modern economics is disappointing, even impoverishing ... In the face of such limitations, why does economics enjoy such prestige? The awkward possibility arises that the reason is precisely because its mod- ern form is ahistorical, apolitical, asocial. Olympian views have appeal to all social orders, and a view that eschews politics and sociology may have special appeal for a social order that celebrates its close relation to science. The nature of the appeal itself is a function of economics we have until now left unexamined. This is its service as ideology not a narrow, consciously self-serving apologia, but a belief system of the kind that accompanies and supports all social orders. The purpose of such belief systems is to provide the moral certitude that is the precondition for political and social peace of mind, as much or more for the dominant elements in any social order as for its subordinate elements. No doubt this peace of mind is always tinged with doubt or tainted with hypocrisy, but in the end, social orders at all levels of hierarchy require some body of knowledge and set of beliefs to which to repair. Primitive societies have their myths and interpretations of nature, command societies their sacred texts. By no means exclusively, but also by no means in a trivial fashion, economics serves that purpose for capitalism as a social order" [37, p. 629630]. The mainstream economics not only does not help to understand reality, but contributes to obscure this understanding: "I am more interested in economics as a veil that obscures our social understanding than as a technique for discovering how our society works. What does the veil obscure? That the price system is also a system of power; ... that the object over which the veil is spread is not a collection of individuals but a specific social order to which we give the name capitalism" [38, p. 7-8].

Robert Heilbroner understood very well the 'theological' nature of mainstream economics and transformed the Schumpeter's notion of vision in the following way: "By vision we mean the political hopes and fears, social stereotypes, and value judgements ... that infuse all social thought" [39, p. 4]. The authors appeal mainstream economists to change their present laissez-faire vision in favour of "a recognition of the necessity for the widening degree and deepening penetration of public guidance into the working of capitalism itself" (Ibid., p. 11). It is just what John Commons tried to do. The vision of social reality, which economists are based upon and develop, influence students and society as a whole. Today economists teach not as markets economy works, what they teach it is the market vision of social reality. Adam Smith expressed this vision in the following way: «Every man thus lives by exchanging or becomes in some measure a merchant, and the society itself grows to be what is properly a commercial society». Garry Becker and James Buchanan have applied this vision to family and political life. This 
vision ignores social responsibility and morality that are vital to the proper functioning of economy and society. The economic, political and social results of the spreading of this vision are horrible: "At the root of America's economic crisis lies a moral crisis: the decline of civic virtue among America's political and economic elite. A society of markets, laws, and elections is not enough if the rich and powerful fail to behave with respect, honesty, and compassion toward the rest of society and the world. America has developed the world's most competitive market society but squandered its civic virtue along the way. Without restoring an ethos of social responsibility, there can be no meaningful and sustained economic recovery" [ 40 , p. 3]. The present day mainstream economics, in spite of its sophisticated mathematical cloths, is nothing else as a pseudo-scientific expression of the neoliberal ideology to the development and spreading of which the post-WWII economists greatly contributed.

At present, another liberalism is needed, it is communitarian liberalism: "John Dewey's writings were especially influential in providing intellectual foundations for communitarian liberalism. Dewey prized individuality but rejected individualism, especially economic individualism. He stressed the realities of interdependence, the virtues of cooperation, and the obligations that attend responsible choice. He combined a spirit of liberation with a strong commitment to effective, self-preserving participation in community" [41, p. 13]. The communitarian liberalism differs not only from neoliberalism, but also from welfare liberalism of John M. Keynes: "American welfare liberalism ... has rejected the individualist assumptions of neoclassical economics about property and choice. Welfare liberals accept many government policies that limit free choice in matters of health, safety, education and conservation ... Welfare liberalism badly needs a forthright acceptance of communitarian principles. This will produce a sturdy hybrid, which we may call communitarian liberalism. The communitarian critique of liberalism has this main complaint: the liberal tradition as we have come to know it in the West lacks an ethic of responsibility. The focus has been on liberty and rights, without much concern for obligation and duty" (Ibid., 10).

We can see many elements of communitarian liberalism in Jean-Jacques Rousseau's essay A Discourse on Political Economy. Gustav Schmoller expressed also many ideas which can be qualified as those of communitarian liberalism. However, the real communitarian liberal among economists of the past was John R. Commons, and he was a true disciple of John Dewey [42]. Now we can say that in the institutional economics of Commons the communitarian liberalism is closely linked the epistemological and social constructivisms. His constructivist institutional economics can be presented as discursive troika [43]: discursive inquiry, discursive (deliberative) policy development, and discourse ethics. All of them must be based on the discursive ontology [44, p. 29]. What we have to investigate in economics are not things and events, but discourses consisting of speech acts. Instead of looking for causal relations, economists have to try to reveal rules of human behaviour. In this respect the economist has to enter into a discourse with economic actors in order "to know what a situation means to a person and not just what the situation is (say, according to a description in terms of its physical characteristics as an observer sees there) if we are to understand what that person is doing" (Ibid., p. 21). Analysis of speech acts should be supplemented by the study of document acts [45]. So the institutional economics, as an investigative activity, represents discourse/text analysis, and this is the first element of the discursive troika. John Dewey thought that "inquiry, indeed, is a work that devolves upon experts. But their expertness is not shown in framing and executing policies, but in discovering and making known the facts upon which the former depend on.

It is not necessary that the many should have the knowledge and skill to carry on the needed investigations; what is required is that they have the ability to judge of the bearing of the knowledge supplied by others upon common concerns" [46, p. 208]. This type of policy development activity is now called the discursive (or deliberative) democracy, and this is the second element of the discursive troika. Any policy development is inevitably accompanied by conflicts. John Commons thought that they may be efficiently solved "when representatives of conflicting organized economic interests, instead of politicians or lawyers, agree voluntarily on the working rules of their collective action in control of individual action" [47, p. 24]. The necessary condition for this efficiency is the argumentational integrity of participants [48, p. 67-78], which is linked to the third element of the discursive troika called the discourse ethics. Without deliberative democracy, there is no demand by the

public for non-deviated inquiry and no large-scale supply of research by economists, as they will not be given the opportunity to conduct their research-investigation. Neither discursive inquiry nor deliberative democracy is possible without discourse ethics. 
At present, the mainstream and orthodox economics are separated from the society. In order to overcome this separation, it is necessary to reconsider the dispute of methods (Methodenstreit) on the basis of the constructivist institutional economics. In addition,unlike traditional economists-experts, that provide only technical information requested by those in power, constructivist institutional economists should communicate their findings to the public whether those in power like the results of these findings or not. It would be possible in this way to link economists and economics with society.

\section{References}

1. Gribbin, J. (2003). Science. A History. 1543-2001. London: Penguin Books.

2. Burtt, E. A. (2003). The Metaphysical Foundations of Modern Science. NY: Dover Publications.

3. Shapin, S. (1996). The Scientific Revolution. Chicago and London: The University of Chicago Press.

4. Shapin, S. (1994). A Social History of Truth. Civility and Science in Seventeenth-Century England. Chicago and London: The University of Chicago Press.

5. Yonay, Y. P. (1998). The Struggle over the Soul of Economics. Institutional and Neoclassical Economists in America between the Wars. Princeton, New Jersey: Princeton University Press.

6. Peirce, C. S. (1992). The Essential Peirce. Selected Philosophical Writings, 1, Bloomington: Indiana University Press.

7. Cunningham, W. (1894). "Why had Roscher so little influence in England ?". Annals of the American Academy of Political and Social Science, 5, November, 317-334.

8. Knorr Cetina K. (1991) "Epistemic Cultures: Forms of Reason in Science", History of Political Economy, Vol. 23, No 1, pp. $105-122$.

9. Friedman, M. (1953). “Methodology of Positive Economics", in Milton Friedman, Essays in Positive Economics, Chicago: The University of Chicago Press, 3-43.

10. Rubinstein, A. (2006). "Dilemmas of an Economic Theorist". Econometrica, vol. 74, 4 (July), 865-883.

11. Mill, J. S. (1836). "On the definition and method of political economy". In D.M. Hausman (Ed.). The Philosophy of Economics. An Anthology. Cambridge: Cambridge University Press. 1994.

12. Mill, J. S. (1843). The system of Logic Ratiocinative and Inductive Being a Connected View of the Principles of Evidence and the Methods of Scientific Investigation. London: Longmans. 1886.

13. Boyle, R. (1690). The Christian Virtuoso showing that by being addicted to experimental philosophy, a man is rather assisted, than indisposed, to be a good Christian. London: T. H. R. B.

14. Fichte, J. G. (1851). The Vocation of the Scholar. London: John Chapman.

15. Engels, F. (2009). The Condition of the Working-Class in England in 1844. New York: Cosimo Inc. Press.

16. Grimmer-Solem, E. (2003). The Rise of Historical Economics and Social Reform in Germany1864-1894. Oxford: Clarendon

17. Tribe, K. (2002). Historical Schools of Economics: German and English. Keele Economics Research Paper, No 2, Keele University.

18. Balabkins, N. W. (1988). Not by Theory Alone ... : The Economics of Gustav von Schmollerand Its Legacy to America. Berlin: Duncker und Humblot.

19. Priddat, B. P. (1995). Die andereÖkonomie. Marburg: Metropolis.

20. Schellschmidt, H. (1997). Ökonomische Institutionenanalyse und Sozialpolitik. Marburg: Metropolis.

21. Peukert, H. (2001a). "The Schmoller Renaissance”, History of Political Economy, vol. 33, 1, Spring, 71-116.

22. Peukert, H. (2001b). "Bridging Old and New Institutional Economics: Gustav Schmoller and Douglass

C. North, Seen with Oldinstitutionalists' Eyes", European Journal of Law and Economics, vol. 11, 2, 91-130.

22a. Shapin, S. \& Schaffer, S. (1985). Leviathan and the Air-Pump. Hobbes, Boyle, and the Experimental Life. Princeton University Press.

23. Berger P. and T. Luckmann. (1991) The Social Construction of Reality, London: Penguin Books.

24. Peirce, C. S. (1998). The Essential Peirce. Selected Philosophical Writings, 2, Bloomington: Indiana University Press.

25. North, D. C. (2003). The Role of Institutions in Economic Development, Occasional paper No.1, New York and Geneva: Economic Commission for Europe, United Nations.

26. Harré, R. (2009). “Saving Critical Realism”, Journal for the Theory of Social Behaviour, vol. 39, 2, 129-143.

27. Harré, R. \& Tissaw, M. (2005) Wittgenstein and Psychology. A Practical Guide. Aldershot, England: Ashgate.

28. Harré, R. \& Secord, P. (1972). The Explanation of Social Behaviour. Oxford: Basil Blackwell.

29. Bloor, D. (1997). Wittgenstein, Rules and Institutions. London; New York: Routledge.

30. Schmoller, G. (1894). "The Idea of Justice in Political Economy", Annals of the American Academy of Political and Social Science, vol. 4 (March), 1- 41.

31. Steuart, J. (1767). An Inquiry into the Principles of Political Economy: being an Essay on the Science of Domestic Policy in Free Nation, vol. I. London: A. Millar and T. Cadell.

32. Hayek, F. A. (1978). "The Errors of Constructivism”. In: F.A. Hayek, New Studies in Philosophy, Politics, Economics and the History of Ideas, Chicago: The University of Chicago Press, 3-22.

33. Salin, P. (2000). Lebéralisme. Paris: Editions Odile Jacob.

34. Rubinstein, A. (2012). Economic Fables. Cambridge: Open Book Publishers.

35. Schmoller, G. (1998). Historisch-ethnische Nationalökonomie als Kulturwissenschaft. Marburg: Metropolis-Verlag.

36. Weintraub E. R. (2001) "Making Economic Knowledge: Reflections on Golinski's Constructivist History of Science", Journal of the History of Economic Thought, Vol. 23, No 2, pp. 277-282. 
37. Heilbroner, R. (2004). "Economics as Universal Science”. Social Research, vol. 71, 3, 615-632.

38. Heilbroner, R. (1988). Behind the Veil of Economics: Essays in the Worldly Philosophy. New York, London: W. W. Norton \& Co.

39. Heilbroner, R. \& Milberg, W. (1995). The Crisis of Vision in Modern Economic Thought. Cambridge: Cambridge University Press.

40. Sachs, J. (2011). The Price of Civilization. Economics and Ethics after the Fall. London: The Bodley Head.

41. Selznick, Ph. (2002). The Communitarian Persuasion. Washington, D.C.: Woodrow Wilson Center Press.

42. Bazzoli, L. \& Dutraive, V. (2014). «Lecture croisée de la philosophie de J. Dewey et de l'économie de J.R. Commons». Revue économique, vol. 65, 2, 357-372.

43. Yefimov, V. (2013). "From Pleasure Machines to Moral Communities (Reflections on a New Book by Geoffrey Hodgson)", Journal of Institutional Studies, vol. 5, 2 (August), 7-47. (in Russian). Available at: http://mpra.ub.uni-muenchen. de/49156/1/MPRA_paper_49156.pdf

44. Harré R. and G. Gillett (1994). The Discursive Mind. Thousand Oaks; London; New Dehli: Sage Publications.

45. Smith, B. (2013). “Document Acts”, In A.Konzelmann-Ziv, H. B. Schmid (eds.), Institutions, Emotions, and Group Agents. Contributions to Social Ontology, Dordrecht, Heidelberg, New York, London: Springer.

46. Dewey, J. (1927). The Public and its Problems. New York: Henry Holt \& Co.

47. Commons, J. R. (1950). The Economics of Collective Action. New York: The Macmillan Company.

48. Ulrich, P. (2008). Integrative Economic Ethics: Foundations of a Civilized Market Economy. Cambridge: Cambridge University Press.

\section{Information about the author}

Yefimov Vladimir Maksovich (Annecy, France) - Doctor of Economics, Associate Professor, Independent Scholar (1745, route de Beffay, Annecy, France, 74130, Petit-Bornand-les-Glières; e-mail: vladimir.yefimov@wanadoo.fr) 